\title{
Distribution of Soviet catches of sperm whales Physeter macrocephalus in the North Pacific
}

\author{
Yulia V. Ivashchenko ${ }^{1, *}$, Robert L. Brownell Jr. ${ }^{2}$, Phillip J. Clapham ${ }^{1}$ \\ ${ }^{1}$ National Marine Mammal Laboratory, Alaska Fisheries Science Center, 7600 Sand Point Way, Seattle, Washington 98115, USA \\ ${ }^{2}$ Southwest Fisheries Science Center, 1352 Lighthouse Ave., Pacific Grove, California 93950, USA
}

\begin{abstract}
From 1948 to 1979, the USSR conducted extensive illegal whaling worldwide. Data from the North Pacific (NP) were analyzed to correct falsified International Whaling Commission catch records and to investigate the distribution of sperm whales Physeter macrocephalus (NP catch $=157680$ ). Information was available on the distribution of 123264 sperm whale catches. Among a number of areas defined by the Soviet whalers, the largest catches were in the 3 main regions: 31395 in the Eastern Region (ER), 29518 in the Central Region (CR), and 19313 in the Western Region (WR); an additional 23090 catches were made at the Kuril land stations. Other areas with substantial catches included the Aleutians (5945) and Commander Islands (1448), the Bering Sea (3170), Olyutorsky Bay (3094), and other parts of the pelagic NP (6049). Four main areas of concentration included: a large pelagic area $\left(30-50^{\circ} \mathrm{N}\right)$ in the ER, including the Gulf of Alaska and western coast of North America; the northeastern and southwestern $\mathrm{CR}_{i}$ and the southern Kurils. Some of the distribution was similar to 19th century catches, notably in the 'Japan Ground' (in the pelagic western Pacific) and the 'Coast of Japan Ground'. Many females were caught in Olyutorsky Bay and around the Commander Islands. There was also a division in catch composition at Amchitka Pass (Aleutians), with family groups to the west and mature males to the east. The extensive illegal catches of females removed a significant portion of the reproductively mature population, which likely continues to impact recovery of NP sperm whales today.
\end{abstract}

KEY WORDS: Sperm whale $\cdot$ Physeter macrocephalus $\cdot$ North Pacific $\cdot$ Whaling $\cdot$ Illegal whaling USSR $\cdot$ Distribution $\cdot$ International Whaling Commission

\section{INTRODUCTION}

Sperm whales Physeter macrocephalus are widely distributed throughout the world's oceans. In general, groups of mature females and juveniles of both sexes (known collectively as 'family groups') ${ }^{\mathbf{1}}$ are believed to live primarily in tropical, subtropical, or mid-latitude waters, while mature males range as far as polar waters, returning to lower latitudes to mate (Best 1979, Whitehead 2003). However, catches and sightings of females and juvenile sperm whales have occasionally been recorded in high-latitude waters (Fearnbach et al. 2012, Mizroch \& Rice 2013). The species shows globally low genetic diversity, and the

\footnotetext{
*Corresponding author: yulia.ivashchenko@noaa.gov
}

structure and division of sperm whale populations has long been a topic of debate at the International Whaling Commission (IWC) and elsewhere (Donovan 1991, Kasuya 1991, Dufault et al. 1999). Various management units have been proposed for this spe-

\footnotetext{
1This term, though widely used in the literature, is strictly inaccurate since recent work has shown that sperm whale groups may be composed of multiple matrilines and thus not necessarily of whales that are all related. Whitehead et al. (2012) instead proposed the term 'social unit', but this could apply to any association of whales; consequently, we have retained the more conventional term here, while recognizing that these 'family groups' may include more than one 'family'
} 
cies in the North Pacific (NP), some based more upon politics than science ${ }^{2}$. Mizroch \& Rice (2013) used Discovery mark data to demonstrate broad movements across the putative boundaries set by the IWC (Donovan 1991) and in current U.S. Stock Assessment Reports (Allen \& Angliss 2013).

Sperm whales were a regular target of commercial whaling from at least the 18th century and were intensively hunted by American and other sail-based whalers through the 19th century (Townsend 1935); the first catches of this species in the NP were made about 1791 (Starbuck 1878). With the advent of steam catchers, factory ships, and modern mechanized whaling techniques, sperm whale populations came under assault, and huge numbers were killed at all latitudes. More than 400000 sperm whales were killed in the Southern Hemisphere in the 20th century alone (Clapham \& Baker 2008, Rocha et al. in press). Until recently, 20th century figures for the NP were unknown, in large part because of uncertainty regarding illegal catches by the Soviet Union (USSR).

The USSR began whaling illegally (that is, ignoring IWC-agreed catch limits, protected species, and other regulations) in 1948..$^{-}$Catches continued until the late 1970s (Berzin 2008, Clapham \& Ivashchenko 2009, Ivashchenko \& Clapham 2014). Worldwide, we estimate that approximately 180000 whales (of all species) were killed and not reported to the IWC (Ivashchenko et al. 2011) during this period. Largescale falsifications of catch data create major problems for the current management of whales because key assessments of both pre-exploitation and current population size rely heavily upon the assumption of an accurate catch record; thus, correcting the falsified catch series is critical to conservation planning.

While the catch record was largely corrected for the Southern Hemisphere some years ago (Yablokov et al. 1995, 1998), major gaps remained in the NP; this was due largely to the comparative unavailability of original (true) catch data for this region. Some NP data were analyzed for catches of various species (in particular see Yablokov \& Zemsky 2000, and

\footnotetext{
2Existing management units for sperm whales in the North Pacific were developed at the IWC parallel to catch quota discussions. In this case fewer defined populations meant higher catch quotas both for Japan and the Soviet Union ${ }^{3}$ At this time such catches were made primarily in the Antarctic, although some right whales Eubalaena japonica were killed illegally in the North Pacific beginning in the same year. Illegal whaling of multiple species in the North Pacific began in 1962, with the introduction of a new large factory ship ('Sovetskaya Rossiya'), with sperm whales taken illegally beginning in 1964
}

papers therein); however, the resulting totals were based upon incomplete information and, in most cases, lacked data from 3 of the 5 Soviet whaling fleets operating in this ocean (Brownell et al. 2000).

A wealth of previously unexamined material from the Soviet whaling industry was discovered by one of us (Y.V.I.) in Russian public archives in 2010. The material in question consists of numerous scientific, production, inspection, and other reports for NP whaling fleets; these were all classified as secret during the period of Soviet whaling but are now declassified and publically available. From this material, we have already assembled and published a corrected catch record for all species in the NP (Ivashchenko \& Clapham 2012, Ivashchenko et al. 2013).

The sperm whale was the target of more Soviet catches than any other species in the North Pacific, with an estimated 157680 taken. While many of these catches were legal under IWC rules, others were not. In addition to incorrectly reporting catch numbers, the Soviets also extensively falsified data on the sex and maturational state of animals in the catch. This situation led the IWC to lower the minimum size limit for females because they believed there had been excessive pressure on males (IWC 1974); in reality, females had already been extensively exploited (Berzin 2008, Ivashchenko \& Clapham 2014). Because of these problems, the officially reported Soviet catch data for the period 1964-1971 (the years of peak catches) were not included in the analysis by Mizroch \& Rice (2013).

A revised catch total for sperm whales was included in the analysis given by Ivashchenko et al. (2013). Here, we use the 'true' Soviet data from the formerly secret whaling industry reports to break down these catches by area in order to gain insights into the distribution of this species in the NP.

\section{MATERIALS AND METHODS}

The data used in this paper to correct the catch record and examine sperm whale distribution derive from various Russian-language sources, consisting of published Soviet literature and the reports from Soviet whaling operations in the NP. The latter are formerly secret reports and represent our primary source of information; they were discovered during searches of public archives in Vladivostok, which was the home port for the Soviet NP whaling fleets. They include: (1) scientific reports summarizing catches by area and time, as well as measurement and biological data, and assessments of the status of species and 
Other problems with conflicting data in different types of reports are summarized in Ivashchenko et al. (2013). As noted there, discussions with biologists and whalers who were present at the time, and familiar with fleet operations ${ }^{\mathbf{5}}$, indicated that the scientific or inspection reports were largely reliable, and accordingly the information in these has been used in any cases of conflict with figures given in production reports.

The Soviet whaling fleets and land stations, and the periods of time in which they were active, are shown in Table 2. At various times, 5 factory fleets were operational, as well as 5 land stations located on 4 islands in the Kurils. Large-scale illegal catches of sperm whales and corresponding data falsification began in $1964^{6}$ and continued until the introduction by the IWC of an Independent Observer Scheme in 1972 (Ivashchenko \& Clapham 2014). The (falsified) catch figures as officially reported by the USSR to the Bureau of International Whaling Statistics (BIWS) were taken from the IWC's catch database (Allison 2012).

Overall catch totals for Soviet sperm whaling operations in the NP between 1948 and 1979 can be divided into 3 parts: (1) 1948-1963, when most catches were legal; (2) 1964-1971, the peak period of illegal catches and data falsifications; and (3) 1972-1979, when illegal catches were effectively precluded by the introduction of international observers onto factory ships (reflected in almost complete agreement between the secret and officially reported data).
Table 2. List of all whaling fleets and land stations operated by the Soviet Union in the North Pacific. The number of catchers in operation varied from year to year

\begin{tabular}{|lccc|}
\hline $\begin{array}{l}\text { Fleet/ } \\
\text { station name }\end{array}$ & $\begin{array}{c}\text { Years of } \\
\text { operation }\end{array}$ & Areas of operation & $\begin{array}{c}\text { No. of } \\
\text { catchers }\end{array}$ \\
\hline $\begin{array}{l}\text { Aleut } \\
\text { Kuril land } \\
\text { stations }\end{array}$ & $1933-1967$ & North Pacific & $3-8$ \\
$\begin{array}{l}\text { Slava } \\
\text { Sovetskaya } \\
\text { Rossiya }\end{array}$ & $1948-1964$ & $\begin{array}{c}\text { Kuril Islands and areas } \\
\text { around ( 200 n miles) }\end{array}$ & $12-15$ \\
$\begin{array}{l}\text { Vladivostok } \\
\text { Dalniy Vostok }\end{array}$ & $1966-1969$ & North Pacific & $10-15$ \\
& $1967-1965,1973$, & North Pacific & $15-25$ \\
\hline
\end{tabular}

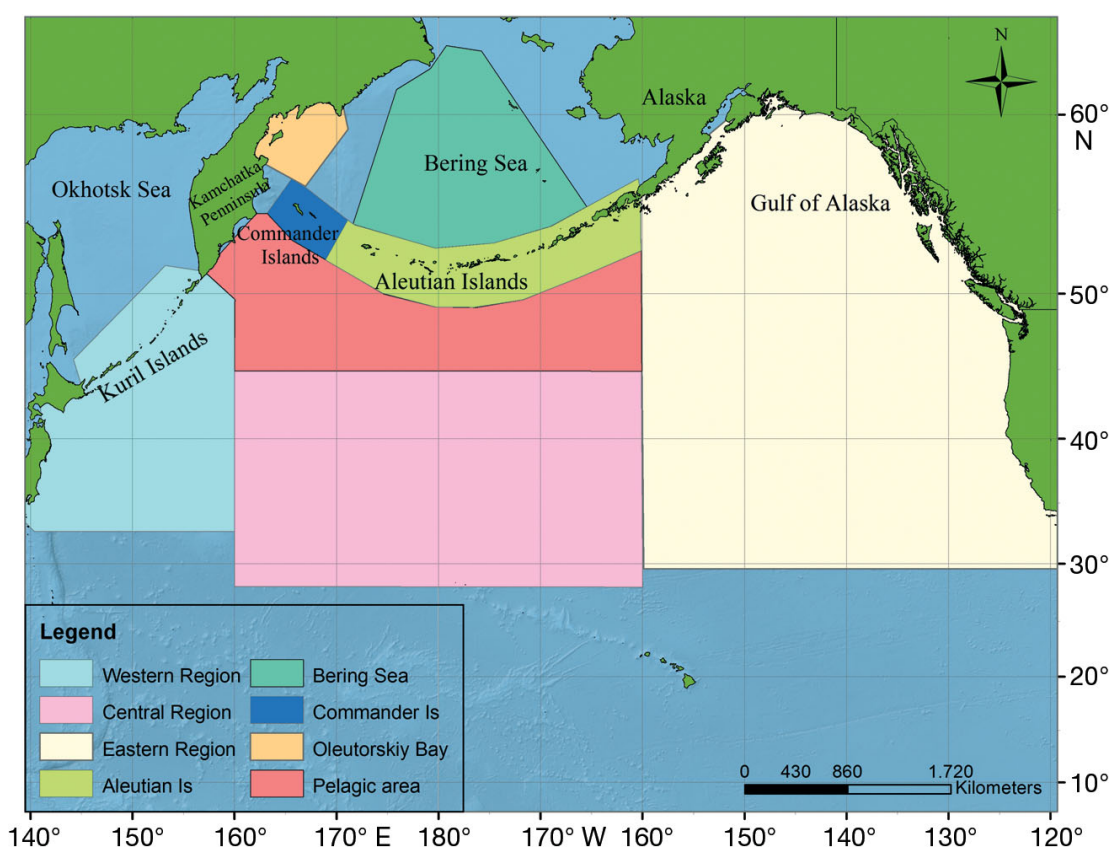

Fig. 1. Main factory ship whaling areas described in (or inferred from) Soviet scientific reports. Definitions of each area sometimes varied by year (see 'Materials and methods: Defining catch areas in the NP'). The Kuril Islands land station catches were separate from those in the Western Region

\section{Defining catch areas in the NP}

In the Soviet scientific reports, catches were usually divided into separate areas, though the definition of these areas is often confusing. Overall, there were 9 areas $^{\mathbf{z}}$ of different sizes used to described whaling effort and catches (see Fig. 1). The 3 primary areas of factory ship operations that were defined in the NP were termed the Eastern Region
${ }^{5}$ Details of the interviewees, and an overview of Soviet illegal whaling operations in general, are given in Ivashchenko et al. (2011)

${ }^{6}$ We take 1964 as the beginning of the period of illegal catches for sperm whales. At this time, sperm whale catches and data falsification increased dramatically, primarily due to a decline in baleen whales and the increased number of Soviet whaling fleets operating in the North Pacific. Illegal catches of other species were occurring before 1964

${ }^{7}$ The Okhotsk Sea was also one of the catch areas, but, because of the low number of sperm whales (242) taken there, it is mentioned only briefly in this paper 
(ER), Central Region (CR), and Western Region (WR, which did not include the Kuril Islands). A number of smaller areas were listed in the northern part of the NP, including the Commander Islands, Aleutian Islands, Bering Sea, and Olyutorsky Bay; some catches that did not fall into one of the defined regions were listed simply as 'pelagic'. Some of the Soviet whaling areas are precisely defined in the reports, while, in other cases, we have had to infer approximate boundaries. However, it should be noted that the definition of some areas changed over time, with some being expanded in later years.

Of all the regions mentioned in the reports, exact boundaries were defined for only the CR $\left(36-45^{\circ} \mathrm{N}, 180-\right.$ $160^{\circ} \mathrm{W}$ ). Over the period from 1964 to 1970 , the definition of the CR boundaries was broadened to $28-45^{\circ} \mathrm{N}$,

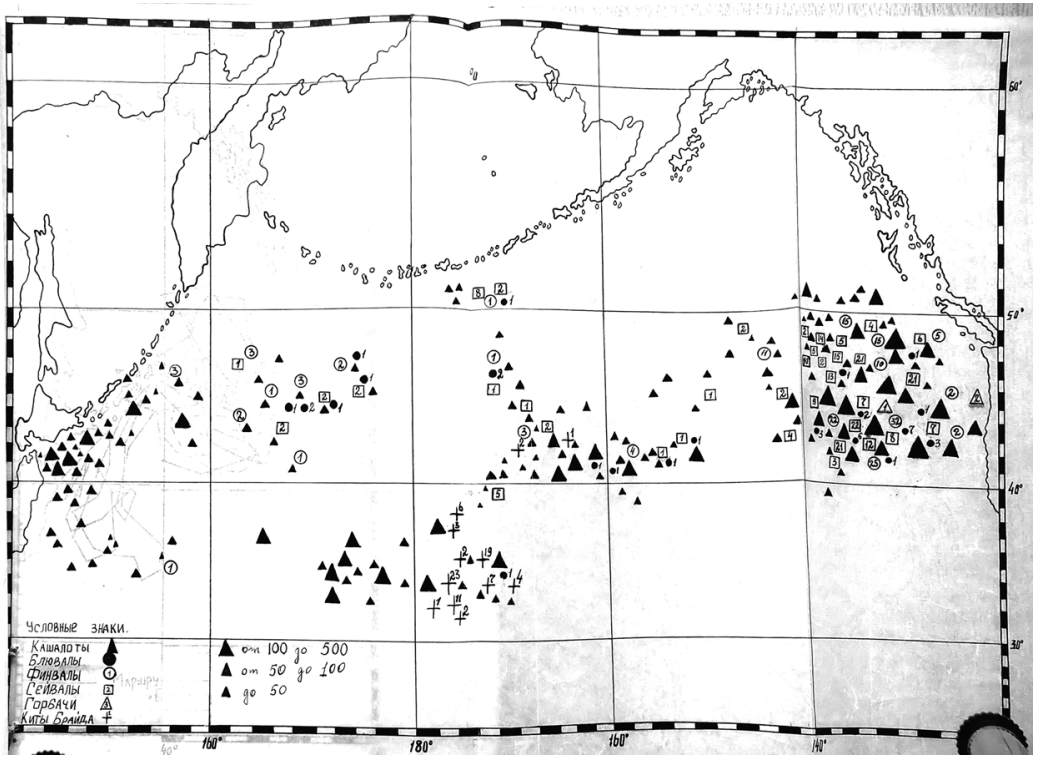

Fig. 2. Example of a map of whale catches, from the scientific report for 1969 for the Slava and Dalniy Vostok whaling fleets. The map shows all hunted species; $\boldsymbol{\Delta}$ : sperm whale catches; the symbol size reflects the number of caught whales $160^{\circ} \mathrm{E}-160^{\circ} \mathrm{W}$, to reflect the expansion of Soviet whaling effort. For 1964, the boundaries of the ER consisted of 2 parts separating the Gulf of Alaska at $140^{\circ} \mathrm{W}$, with the western boundary lying at the longitude of Unimak Pass, and with no borders to the south. In a whaling journal from a later year (1967), these areas were combined into a single region, with the western boundary set at $150^{\circ} \mathrm{W}$. Beginning in 1968, this boundary was moved to $160^{\circ} \mathrm{W}$ to abut the eastern boundary of the CR.

The WR was not defined by exact boundaries until 1968, when the eastern and western limits were initially set at $143^{\circ} \mathrm{E}$ and $155^{\circ} \mathrm{E}$, respectively; in later years the WR was expanded to abut the CR boundary at $160^{\circ} \mathrm{E}$. In addition, its southern boundary was variable, with an expansion from $35^{\circ} \mathrm{N}$ to about $30^{\circ} \mathrm{N}$ in 1972. Although the Kuril Islands fell within the WR, the latter refers only to catches made by factory fleets, and the Kurils land station catches were reported separately.

For other regions, defined with reference to major geographic features such as the Bering Sea, Commander Islands, and Olyutorsky Bay, the reports assume an understanding of the general location of these places, and boundaries were chosen by us to reflect the catch concentration in these areas. For the Aleutian Islands, the boundaries were defined to follow the $1000 \mathrm{~m}$ isobath, with a $100 \mathrm{n}$ mile buffer on the Pacific side; this also reflects the concentration of catches in this area.

\section{Assigning catch distribution in the NP}

The distribution of sperm whale catches is shown in some but not all scientific reports; an example is shown in Fig. 2. Maps from the reports were georeferenced (using Arc GIS 10) to yield catch positions. A database of catch positions was created to provide a more precise understanding of the distribution of true sperm whale catches by Soviet whalers.

In the reports where catches were listed by month, the maps of fleet tracks were used to assess the coverage area during given periods; an example from a Soviet scientific report is shown in Fig. 3, and all available tracks for the period 1964-1971 are plotted in Fig. 4. Soviet whaling fleet noon positions in the IWC database were used for the years in which precise positions were available; for some years the track line and fleet noon positions were georeferenced from maps given in scientific or inspectors' reports.

Overall, the resolution of location information in the Soviet reports varies widely and assigning catches to particular areas is in some cases impossible, while in others it requires integration of additional information. The data, and the challenges associated with analyzing them, are described in detail in the Supplement at www.int-res.com/articles/suppl/n025p249 _supp.pdf. 


\section{RESULTS AND DISCUSSION}

\section{Sperm whale catch totals}

Sperm whales represented $>80 \%$ of the Soviet catch of all whales in the North Pacific Ocean. The total catch for the period 1948-1979, including a correction factor for unknown catches in 3 years for which no data were available (1963 for Dalniy Vostok, and 1966 and 1967 for Slava), was 157680 whales. ${ }^{\mathbf{8}}$ Of these, 132505 were reported to the BIWS (i.e. 25175 were under-reported). Totals by factory fleet and for the Kuril land stations are given in Table 3 . The introduction of new whaling fleets and the consequent geographic expansion of whaling effort increased catches substantially. From 1966 on, sperm whales made up $80-85 \%$ of the total Soviet catch of all species, with the majority of the catch consisting of females.

Of the estimated 157680 sperm whale catches from 1948 to 1979, 123264 could be assigned to an area, which included 57945 whales taken in 19641971 (Table 4). The major areas of concentration were the WR (total catch = 19313), CR (29518), ER (31 395), and the Kuril Island land stations (23 090). Catches which could not be assigned to a single area are summarized in Table 5.

The analysis of available information regarding sex ratio provided data for 55383 sperm whales, with location details for 31921 females and 23462 males (Table 4). Further details on catches by area are given in the section 'Sperm whale distribution', below.

\section{Kuril Islands land stations}

There were 5 Soviet shore whaling stations on 4 Kuril islands: Kasatka and Yasniy stations on Iturup Island, Skalistiy on Simushir Island, Ostrovnoy on Shikotan Island, and Podgorniy on Paramushir Island. The total catch for sperm whales taken from these 5 land stations was estimated to be 23090 animals, all caught between 1948 and

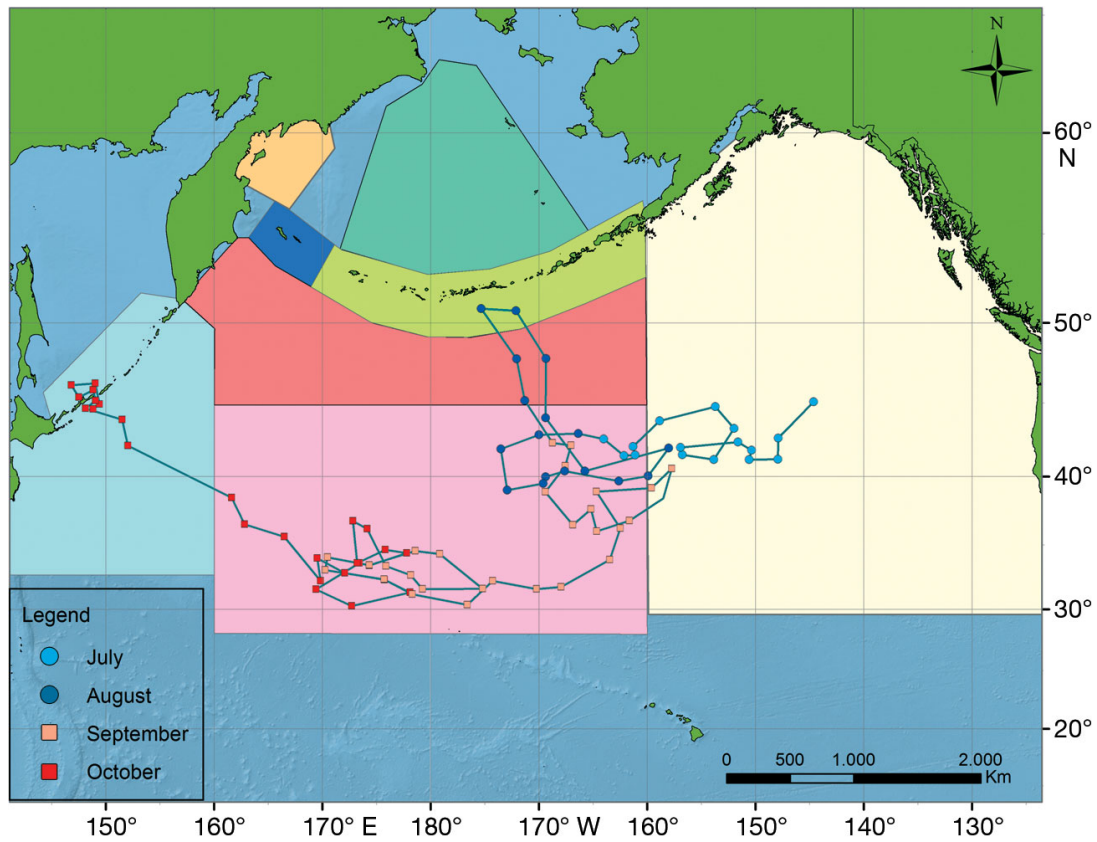

Fig. 3. Example of a fleet track used to assess coverage area, by month, for the Dalniy Vostok fleet in 1969

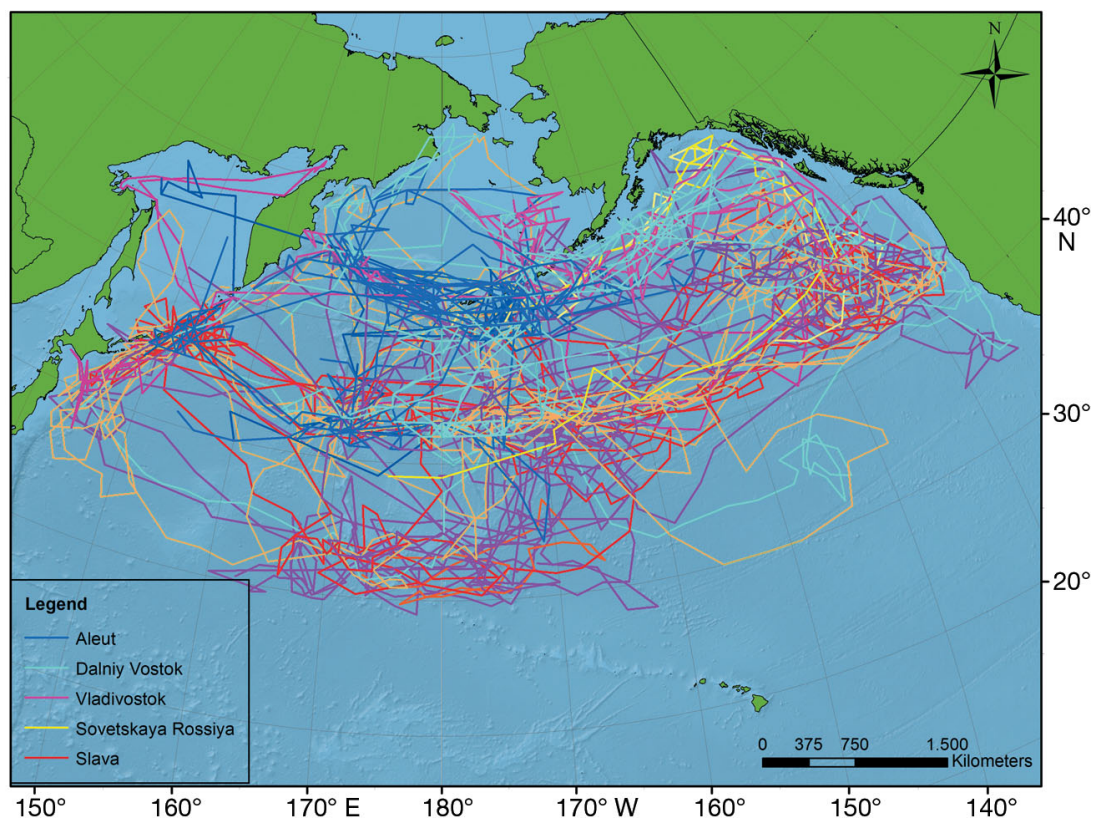

Fig. 4. Tracks of Soviet factory fleets, 1964-1971. Note: track data were not available for all fleets for all years

${ }^{8}$ Note that this is slightly different from the figure published in Ivashchenko et al. (2013) because, following publication of that paper, previously missing catch data were found for the factory fleet Vladivostok's 1969 whaling season 
Table 3. Physeter macrocephalus. Soviet factory fleet or land station catches of sperm whales in the North Pacific, 1948-1979, including a correction factor that estimates the number of whales taken in 3 years for which no data were available (1963 Dalniy Vostok, and 1966 and 1967 for Slava). Note that these figures are slightly different from those published in Ivashchenko et al. (2013) because new information became available after publication

\begin{tabular}{|ccccccccc|}
\hline & Aleut & Kuril Islands & Sovetskaya Rossiya & Vladivostok & Dalniy Vostok & Slava & Correction & Total \\
\hline Total & 22708 & 23090 & 5529 & 36943 & 51095 & 14315 & 4000 & 157680 \\
\hline
\end{tabular}

Table 4. Physeter macrocephalus. Summary of Soviet sperm whale catches in the North Pacific, by region, for the entire period (1948-1979) and for the subset of catches from the peak period of illegal whaling (1964-1971). The latter also gives data on sex (F: female; M: male), where known ( $\mathrm{n}$ 55383). WR: Western Region; CR: Central Region; ER: Eastern Region; Al: Aleutian Islands; Com: Commander Islands; BS: Bering Sea; OlBay: Olyutorsky Bay; OkSea: Okhotsk Sea. The column 'pelagic' represents catches made in offshore waters that did not fall into any of the defined areas. -: no data available

\begin{tabular}{|lccccccccrrr}
\hline & Kurils & WR & CR & ER & Al & Com & BS & Pelagic & OlBay & OkSea & Total \\
\hline $1948-1979$ & $23090^{a}$ & 19313 & 29518 & 31395 & 5945 & 1448 & 3170 & 6049 & 3094 & 242 & 123264 \\
$1964-1971$ & & & & & & & & & & \\
Total & & 8025 & 21573 & 23738 & 1585 & 1448 & 555 & 814 & 207 & 0 & 57945 \\
F & & 4871 & 10831 & 13231 & 79 & 492 & 1 & - & 32 & 31921 \\
M & 2698 & 9273 & 7543 & 734 & 205 & 253 & - & 34 & 23462
\end{tabular}

${ }^{\text {a}}$ Sperm whales killed from the Kuril Island land stations were all caught during the period 1948-1964. The sex ratio, where known, was 4822 females and 17604 males

Table 5. Physeter macrocephalus. Soviet catches of female and male sperm whales, 1964-1971, that could not be assigned to a single area of the North Pacific. CR: Central Region; ER: Eastern Region; Al: Aleutian Islands; BS: Bering Sea; WR: Western Region. The term 'multiple' means catches that could not be localized to a specific region because the fleet moved through 2 or more regions during the period in which the catch data were summarized. -: no data avilable

\begin{tabular}{|lcccccc|}
\hline & ER-CR & ER-Al & Al-BS & CR-WR & Multiple & Total \\
\hline Total & 2150 & 606 & 925 & 78 & 2125 & 5884 \\
Females & 1485 & 122 & - & 0 & 777 & 2384 \\
Males & 1455 & 484 & - & 78 & 705 & 2722 \\
\hline
\end{tabular}

1964. All documents available on the details of the catches showed identical numbers between those given in the reports and the figures reported in the IWC database (for all species except North Pacific right whales Eubalaena japonica). Based upon these records, we have no reason to believe that any of the Kurils sperm whale catch numbers were falsified. Concerning falsifications of the sex ratio data, we found only 1 journal that listed the sex of caught animals, and the numbers given are the same as those officially reported to the IWC. Given that the minimum legal length for a sperm whale was lower for land stations $(10.7 \mathrm{~m}$ or $35 \mathrm{ft})$ than for pelagic operations, the whalers had no reason to change the catch numbers or the sex ratio for these whales. However, there was good evidence that some 'stretching' ' of whales under the legal size was happening regularly (G. Derviz pers. comm. October 2008, Anonymous 1956).

The composition of the Soviet catch in the Kurils by sex, where known, was 4822 females and 17604 males (Allison 2012). This is a very different sex ratio from that reported by Japan for the nearby Hokkaido land station between 1960 and 1965, when females predominated in the catch (2544 females vs. 957 males; Kasuya \& Miyashita 1988). The Soviet data for almost the same period (1960-1964) included 1006 females and 4278 males, but it should be noted that almost all of these were taken in the northern Kurils, far from Hokkaido.

\section{A note on catches by the Aleut fleet}

The Aleut was the first Soviet whaling factory ship; this relatively small vessel began operations in 1933, and was the only Soviet factory fleet operating in the NP until 1962. Although it is likely that some underreporting began around 1964 (only one report gives some details), we consider that the level of falsifi-

\footnotetext{
'9'Stretching' was a common problem in all whaling operations, when (to avoid infractions) whales just below the legal minimum size were reported as longer, thus creating an artificial peak in whales at the lowest values for legal catches
} 
cation for sperm whale catch numbers by the Aleut fleet was low (see Ivashchenko et al. 2013, p. 65-67, for additional details on this point). One journal reported data on whale length measurements from the 1964 season and provided numbers that, for some but not all species, were higher than those officially reported: this included 1662 (true) versus 1369 (reported) sperm whales. In the report of whale length measurements, 441 of the 1662 sperm whales were listed as female. While we know that only 168 of the 441 females were reported to the IWC, we have no way of assessing the overall composition of the 293 under-reported whales (i.e. whether they were lactating females, calves, or under-sized animals of either sex). It is likely that some under-reporting occurred in the Aleut's final few years of operation (1964-1967) due to rising competition and other factors. Except for the one journal, there was no information to assess the extent of under- and mis-reporting. However, in reality the limitations of this old, small fleet would likely not allow catches much larger than those officially reported to the BIWS; our best guess is that the difference in catch numbers lies in the low hundreds. Consequently, for the catches summarized here, officially reported data from the Aleut fleet were used on the assumption that if there were unreported takes, these would be too low to significantly increase the total. In addition, the assumption has been made that there was no falsification of the sex ratio in Aleut's sperm whale catch; however, given the unavailability of scientific reports for this fleet for certain years, we have no way of verifying this.

\section{Sperm whale distribution}

Only a portion of the total sperm whale catch by the USSR during the peak years of 1964-1971 was analyzed for distribution and sex composition, due to the limited number of reports containing such details. Of 90673 sperm whales killed by Soviet pelagic fleets during 1964-1971, we could assign 57945 whales to a particular region (Table 4). Another 5884 catches were 'shared' between 2 or more neighboring regions (Table 5); these were catches that were summarized in the reports by month, during months in which the fleet operated in $>1$ area, making it impossible to determine in which region the catches were made. Exact catch positions were obtained for 42020 sperm whales.

The distribution of all Soviet pelagic sperm whale catches during 1948-1979 for which some location data were available (representing 81035 out of a total of 157680 whales taken during this period) is shown in Fig. 5; these data are also represented as point densities in Fig. 6. Distribution by sex constitutes a separate database, since the data on sex ratios were always given by catch region; consequently, they cannot be directly linked to the individual catch locations but only to the region overall.

Four main areas of concentration are evident in the catches: a large pelagic area $\left(30-50^{\circ} \mathrm{N}\right)$ in the $E R$, including the Gulf of Alaska and western coast of North America; the northeastern and southwestern $\mathrm{CR}_{i}$ and the southern Kurils/northern Japan.

\section{Kuril Islands land stations}

The catches for all species from the land stations were originally reported to the BIWS with only a single position given (middle Kuril Islands). The distribution of sperm whale catches by individual years was not available. However, data on the distribution of catches and sightings for sperm whales were found in reports that summarized the information broken down into 2 periods: 1951-1956 and 1958-1961 (Klumov 1959, Tarasevich \& Borisov 1962). During these years, $>15000$ sperm whales (out of the Kurils total of 23 090) were killed and processed. The areas of catch concentration are shown for both periods by month in Fig. 7.

The main catch concentrations occurred primarily in the middle of the Kuril Islands chain, although there was a somewhat broader dispersion of catches in June and July. Changes in the distribution of effort and catches between the 2 periods (1951-1956 and 1958-1961) reflected a decrease in sperm whale abundance around the Kurils: specifically, in later years catches became concentrated farther offshore and to the north when sperm whales became rare in the southern Kurils (Tarasevich \& Borisov 1962). Although this decline in numbers may have partly reflected a distribution shift in response to changes in oceanographic conditions and prey abundance, it was more likely due to severe depletion from the intensive whaling in the region.

\section{Eastern Region}

The ER was the focus of intensive sperm whale catches from 1964 through 1970. Overall 23738 whales were killed there during this period, including 13231 females and 7543 males (Table 4); for the entire period from 1948 to 1979, the catch 


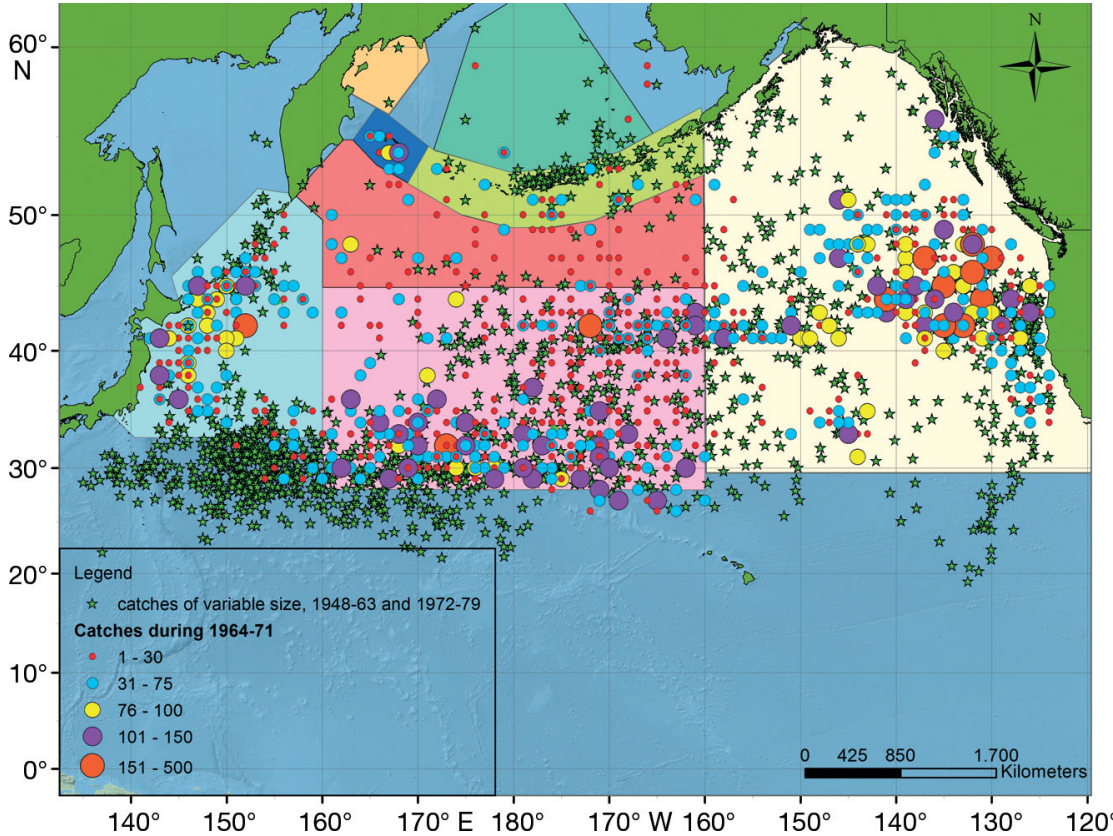

Fig. 5. Physeter macrocephalus. Distribution, where known, of Soviet pelagic sperm whale catches in the North Pacific $(n=81035)$. Green stars represent catches which are known to be of variable size but for which numbers often could not be determined; the catch size could be anywhere from 1 to $>100$ whales (e.g. the 2 stars to the west of Kamchatka in the Okhotsk Sea are known to represent $>200$ whales). Catches made by the Kuril Island land stations $(n=23090)$ are not included

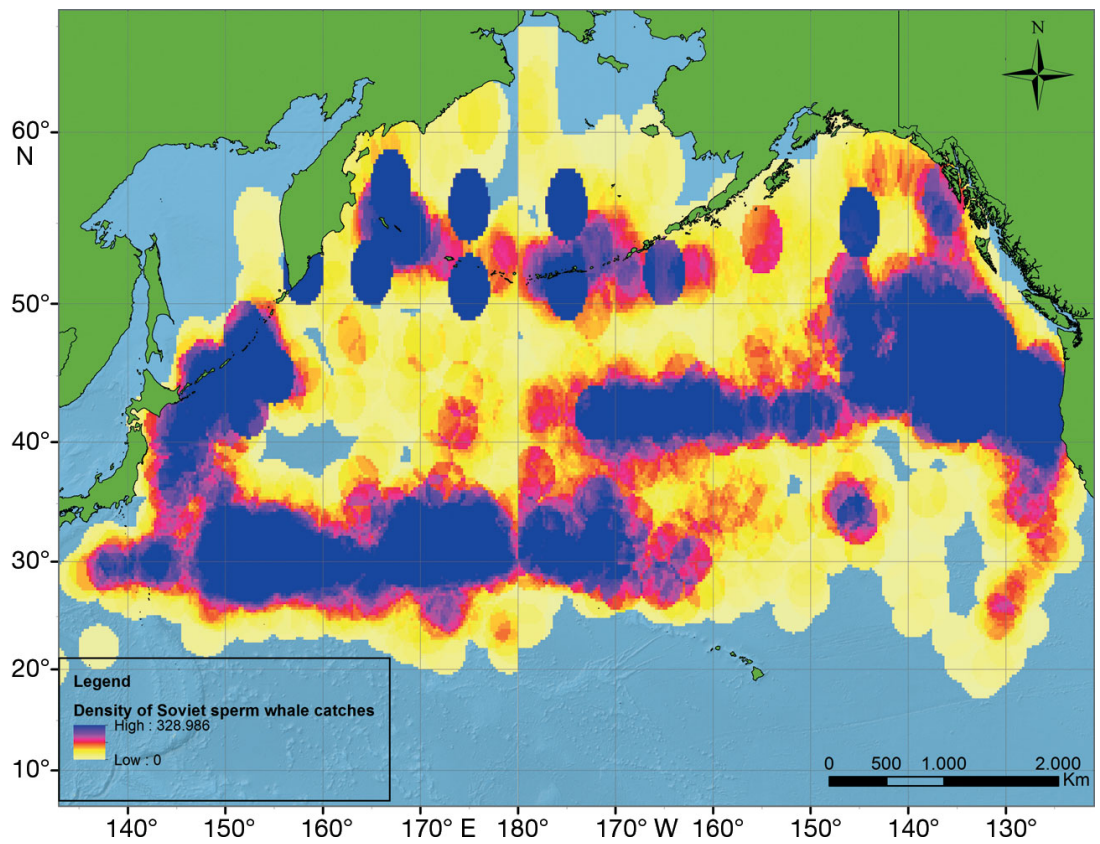

Fig. 6. Physeter macrocephalus. Soviet sperm whale catches shown as point densities

total was 31 395. The main concentration of sperm whale catches, represented primarily by family groups, was distributed over a large area between $40-52^{\circ} \mathrm{N}$ and $126-145^{\circ} \mathrm{E}$. The catches were so intense that by 1969 the level of catches overall and the number of large animals taken had already significantly declined, and from 1970 on this region was targeted only occasionally.

The Gulf of Alaska was part of the ER, but we should note that it was defined in the whaling reports more broadly than the accepted geographic definition today; specifically, for the Soviets, the term meant the region north of a line from Umnak Pass (Aleutians) to northern British Columbia. Sperm whale catches were made throughout this area, but unfortunately we do not have individual details that link the positions and sex of these catches to provide a more detailed analysis of the use of this region. Although some catches in this area are shown in Figs. $5 \& 6$, it is important to realize that we do not have locations for all takes; in particular, large catches made there in 1964 are not shown, because the scientific report for that year gives only the number of whales caught in the area (1779) without a plot of the catch locations. Our rough estimate of the number of sperm whales taken in the Gulf of Alaska (as defined by the USSR), deduced from catch figures and vessel track data, is from 3000 to 4000 animals; 2232 of these were killed in 1963-1964.

Only one scientific report (Doroshenko et al. 1965) covers details of sperm whale catches in the Gulf of Alaska, separating this area into 2 parts (from Umnak Pass to $140^{\circ} \mathrm{E}$ and the area east of $140^{\circ} \mathrm{E}$ ). In both areas, females made up the majority of individuals caught, especially east of $140^{\circ} \mathrm{E}$ where females comprised $80 \%$ of 842 sperm whales. Catches in the western part of the ER featured a mix of females and males of different sizes, although the report mentioned that large males were caught closer to the western boundary of the Gulf of Alaska (specifically the Fox Islands and farther west). 

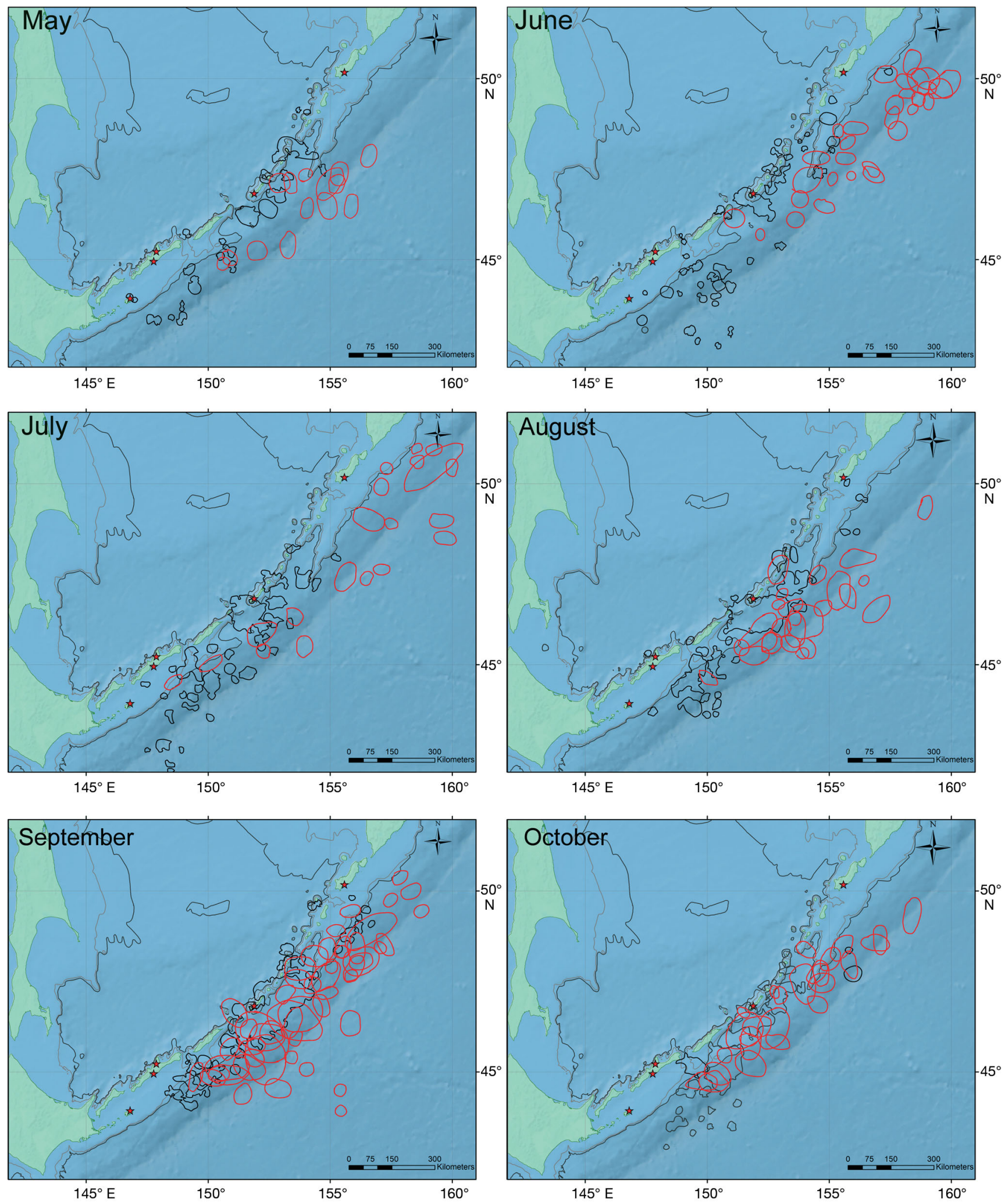

Fig. 7. Physeter macrocephalus. Distribution of sperm whale catch concentrations around the Kuril Islands, by month. Areas of concentration of catches during the periods 1951-1956 (black outline) and 1958-1961 (red outline). The red stars show the locations of land whaling stations 


\section{Central Region}

Catches of sperm whales in this region began in 1965, and in just a few years the primary focus of Soviet whaling moved from the ER to the CR. The total catch during 1964-1971 in the CR was 21573 whales, with 10831 females and 9273 males killed (the remainder were of unknown sex); totals for 1948-1979 were 29518 (Table 4). This region had 2 main catch concentration areas: the northeastern portion (north of $38^{\circ} \mathrm{N}$ ) and the southern portion (all parts of the CR south of $38^{\circ} \mathrm{N}$ ). These 2 areas were very different in catch compositions. While catches in the northeastern area included many large mature males, catches in the southern area were composed of major concentrations of family groups, with many lactating and pregnant females.

\section{Western Region}

Catches of sperm whales by the Soviet pelagic fleets in the WR were concentrated south of $45^{\circ} \mathrm{N}$. While catches until 1971 were limited to areas north of $35^{\circ} \mathrm{N}$, in later years the Soviet effort moved farther south to around $30^{\circ} \mathrm{N}$ latitude. During 1964-1971, 8025 sperm whales were killed, including 4871 females and 2698 males; 19313 whales were taken during 1948-1979 (Table 4). The primary component of the catch was family groups; however, large mature males could still be found, notably in the northern part of the Kurils during late spring or early summer, and in smaller numbers throughout the summer and autumn all around the Kuril Straits (the passes between islands).

\section{Bering Sea}

Catches of sperm whales in the pelagic Bering Sea region (excluding the Aleutians and Commander Islands, and Olyutorsky Bay) became increasingly limited as the Soviet whaling fleets moved farther south to explore other areas of the NP. During 1948-1979, 3170 sperm whales were killed in the Bering Sea, 555 of these in the peak period of 1964-1971. The sex composition of the latter catch was almost exclusively male (253 males vs. only 1 known female). The majority of Soviet catches were made on the shelf edge in the eastern Bering Sea (as were many Japanese catches of this species; Mizroch \& Rice 2013).

\section{Olyutorsky Bay}

Catches of sperm whales in the region of Olyutorsky Bay, on the western side of the Bering Sea, are known from only 2 years during the peak illegal period (1964 and 1966). True catch information was available only for 1964, when 207 whales were killed there; the sex ratio was almost even (32 females and 34 males). However, a total of 3094 sperm whales were killed in this area during 1948-1979. Overall, Olyutorsky Bay (which lies at roughly $55-60^{\circ} \mathrm{N}$ ) seemed to have been occupied by mixed groups that contained a high proportion of females. This, and similar catches of family groups from the Commander Islands (following subsection), contradict traditional assumptions that female sperm whales are largely confined to lower latitudes, and adds to recent discussion of similar catches and sightings (Fearnbach et al. 2012, Mizroch \& Rice 2013). It appears likely that females at least occasionally travel to higher-latitude habitats, presumably in response to favorable oceanographic conditions and the occurrence of prey (Tarasevich 1965, 1968).

\section{Commander Islands}

Catches around the Commander Islands were always intensive and consisted largely of family groups of sperm whales. The total known catch in this area was 1448 whales (all taken during the period 1964-1971), including 492 females and 205 males. It appears that areas around the Commander Islands, Olyutorsky Bay, and the western Aleutians (see following subsection) were occupied by sperm whale family groups, unlike the areas to the east for which the catch was primarily of large mature males; this is discussed further below.

\section{Aleutian Islands}

The total Soviet catch for the Aleutians was 5945 whales; of these, 1585 whales were taken in 19641971, including 79 females and 734 males. We do not have separate estimates for the 2 sub-areas, since the only data on numbers and composition come from catches made in 1964 (Doroshenko et al. 1965). In other years information in the reports was limited to comments on the differences in catch composition between the eastern and western Aleutians. Many Japanese catches of sperm whales were concentrated in this area, especially in the eastern sector (Allison 2012, Mizroch \& Rice 2013). 


\section{Other areas}

Other areas in the NP where catches of sperm whales occurred were the Okhotsk Sea and the socalled 'pelagic' region. Catches in the Okhotsk Sea ( $\mathrm{n}=242$ ), outside the area immediately north and west of the Kuril Islands, were insignificant, and the Okhotsk Sea was never mentioned in the reports as a separate area.

The pelagic region was defined as the area between the boundaries of the Aleutian and Commander Islands to the north and the $\mathrm{CR}$ to the south, with part of the WR and the eastern coast of Kamchatka on the west margin, and the CR to the east. Sperm whale catches were distributed throughout this area, with no obvious concentration(s). The total catch was 6049 sperm whales, with 814 taken during 1964-1971; no information was available on the sex or length composition of these animals.

\section{Catch distribution by sex and maturational status}

A graphical overview of the distribution of animals by sex and maturational status by region is provided in Fig. 8. As expected from previous studies of sperm whales (Best 1979, Whitehead 2003), catches in lower latitudes were dominated by fe- males and mixed family groups, and catches in higher latitudes were primarily of mature males. However, there were some interesting exceptions in the data: (1) the occurrence of many mature males in mid-latitudes of the central $\mathrm{NP}_{\text {; }}(2)$ the predominance of family groups in the western Aleutians and Commander Islands; and (3) the occurrence of females in the Olyutorsky Bay region of the western Bering Sea. Mizroch \& Rice (2013) stated that there were very few females north of the Aleutian Islands in the (primarily Japanese) catch data they analyzed, but noted occasional observations of females in the Aleutians by others (Berzin 1972, Fearnbach et al. 2012). The Soviet catches of females in higher-latitude areas (made primarily in August to October) reinforce the idea that sperm whale distribution is more complex than previously thought.

Of further interest is an apparent division of catch composition in the central Aleutians around $180^{\circ}$, in the vicinity of Amchitka Pass, with family groups to the west and mature males to the east. This division somewhat parallels the situation with present-day, transient-type (mammal-eating) killer whale Orcinus orca populations, which also shows a sharp division in genetic structure across Amchitka Pass (K. Parsons pers. comm. March 2014). The reason for this rather pronounced division in sperm and killer whale populations is not clear.

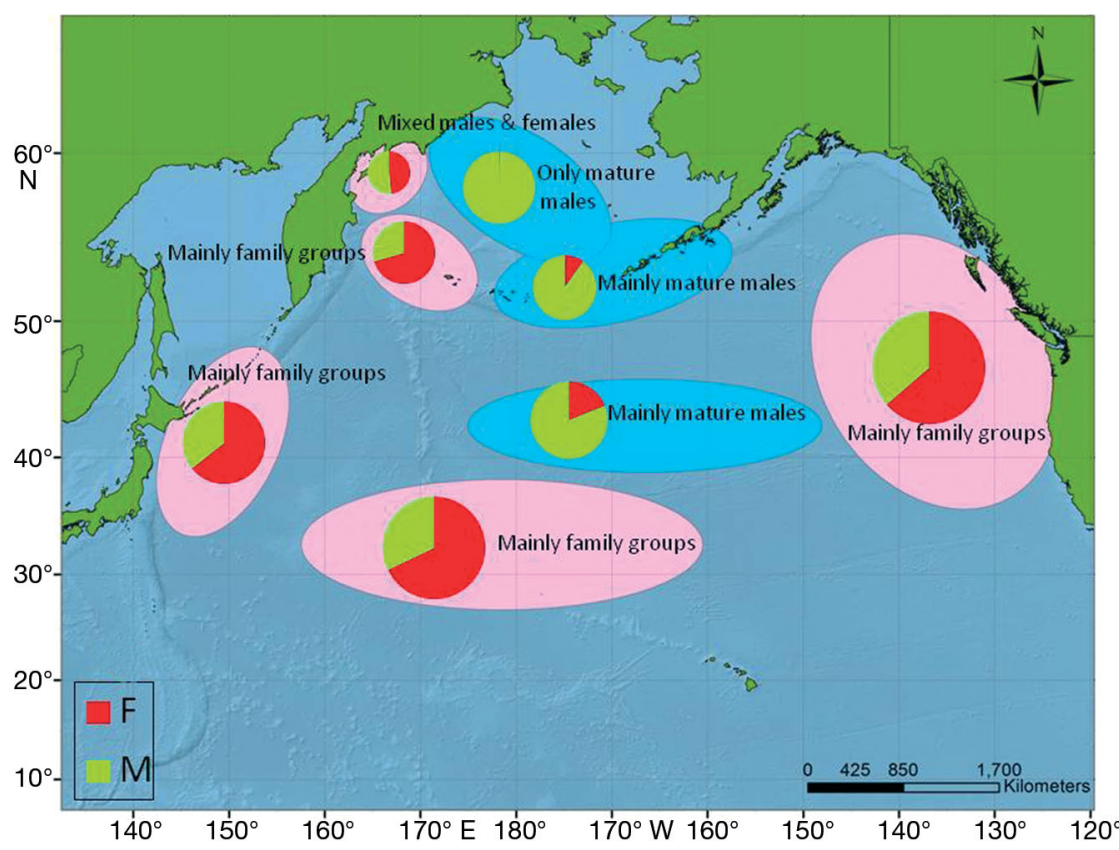

Fig. 8. Physeter macrocephalus. Composition of Soviet catches of sperm whales (F: female; M: male) by area. The size and shape of the ellipses are not intended to represent exact regions but rather to highlight general areas of concentration

\section{Comparisons to other whaling data}

Fig. 9 shows the distribution of catches by Yankee whalers, primarily during the 19th century, derived from Townsend's (1935) analysis (see also Smith et al. 2012). A comparison of Fig. 9 with the pelagic Soviet catches (Figs. 5 \& 6) shows a major overlap in the area known to Yankee whalers as the 'Japan Ground', located in the western NP, roughly between latitudes $26^{\circ}$ and $36^{\circ} \mathrm{N}$. This area of sperm whale concentration overlaps with what is known as the Kuroshio Extension Bifurcation Region (Qiu 2001, Yasuda 2003), where meanders and eddies of the Kuroshio Extension Current drive what is believed to be some of the highest primary productivity in the NP (Polovina et al. 2006). The consistent abundance of sperm whales in 


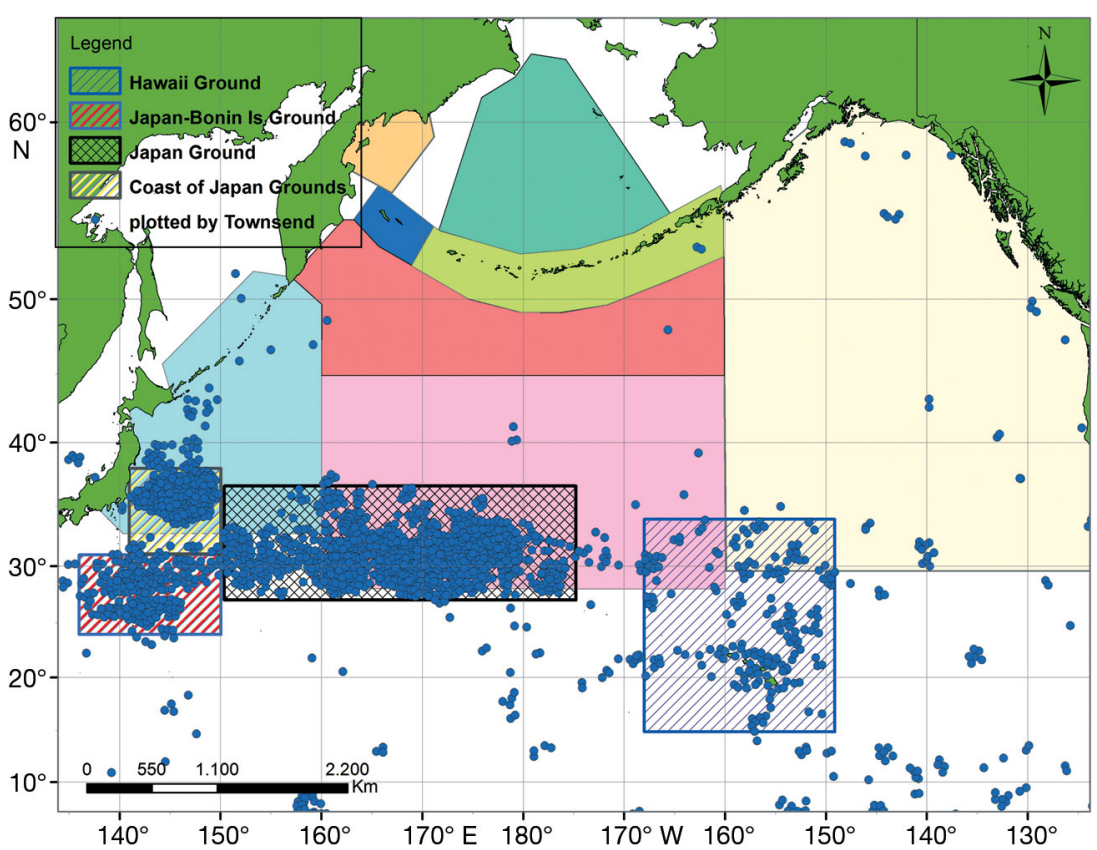

Fig. 9. Major areas of concentration of American (Yankee) whaling catches in the 19th century (from Townsend 1935). Hatched rectangles show the primary 19th century whaling grounds. Colored regions represent Soviet catch areas used in Fig. 5

this area, both historically and during the Soviet whaling era, indicates that this has long been an important foraging area for this species, and likely continues to be so.

Additional overlap between the Yankee and Soviet catches is observed on the 'Coast of Japan Ground' and (to a somewhat lesser extent in terms of the number of 19th century catches) the 'Japan-Bonin Island Ground' to the south. The low (or zero) density of 19th century whaling catches in areas where the Soviets killed numerous sperm whales, including the eastern NP, Gulf of Alaska, Aleutians, and Bering Sea, was almost certainly a function of limited effort in the Yankee fishery, not of an absence of sperm whales from such areas in historical times.

Mizroch \& Rice (2013) plotted catches of sperm whales in the NP (minus the Soviet catch data, which at the time were uncorrected and known to be false) and not surprisingly found similar patterns of distribution to those in the present study.

\section{SUMMARY AND CONCLUSIONS}

The number of sperm whales Physeter macrocephalus killed in the NP in the 20th century was quite staggering. Rocha et al. (in press) calculated that from 1900 to 1999, some 314942 sperm whales were killed in this ocean; for comparison, the combined total catch of all baleen whale species in the NP was estimated by the same authors at 248661 whales. In the period following World War II, pelagic catches alone by the USSR and Japan exceeded 180000 sperm whales; if coastal catches are included, the total is almost 280000 . Clearly the sperm whale was historically the most abundant species of large whales in the NP.

During the peak catch period (19641971), Soviet fleets swept much of the NP (Fig. 4 provides a partial picture of the range of the search effort). The impact of such intense catches undoubtedly left sperm whales severely depleted in this ocean: the combination of high catch numbers and removal of a large percentage of mature females created the situation in which a major portion of the reproductively mature population was removed in virtually all parts of the NP.

A reliable assessment of the current status of this species is very difficult for a number of reasons, primarily because of the considerable expense and effort involved in surveying the vast area that comprises the sperm whale's range in this ocean. There is no currently published estimate for the western or central NP. Wade \& Gerrodette (1993) gave an estimate of abundance of 22700 sperm whales using data from vessel surveys over a large area of the eastern tropical Pacific. Joint acoustic and visual linetransect surveys over a 7.8 million $\mathrm{km}^{2}$ area of the eastern temperate NP in the spring of 1997 were conducted by Barlow \& Taylor (2005). This study produced estimates of abundance of 32100 (coefficient of variation, $\mathrm{CV}=0.36)$ and $26300(\mathrm{CV}=0.81)$ sperm whales, respectively, for the 2 methods, with no significant difference between them. That this estimate was much larger than the figure of Wade \& Gerrodette (1993), despite being from a smaller area, may reflect a negative survey bias due to under-counting of group size (Barlow \& Taylor 2005).

It is worth noting that large aggregations of the kind exploited by the Soviets were never encountered in the Barlow and Taylor surveys (J. Moore pers. comm. April 2014), which presumably reflects the extensive depletion by whaling in this and other areas of the NP; the largest aggregation they found was one of 37 animals. To give just one contrasting 
(and by no means exceptional) example, in only $2 \mathrm{~d}$ in 1963 (31 May and 1 June), the factory fleet Sovetskaya Rossiya killed 538 sperm whales slightly to the north of the Barlow and Taylor survey area.

The population structure of sperm whales in the NP is still unclear, and the present study offers little insight with which to clarify this issue (more detailed analyses of the occurrence and distribution of sperm whales using Soviet data on sex, length, and month are in progress). However, prior to this study the unknown extent of the Soviet falsifications in NP sperm whale catches left the catch record uncertain and thus precluded assessments by the IWC and others of the initial (pre-whaling) population size. Such an assessment is now feasible. In addition, the data reported here add to earlier accounts of the occurrence of sperm whales which indicate an extensive offshore distribution; as noted above, this inevitably complicates population assessments because of the problems of conducting surveys in such remote habitats.

The occurrence of many females in the western Aleutians and western Bering Sea, together with what may be a distinct boundary in catch composition around Amchitka Pass in the Aleutians, is a phenomenon that merits further investigation. Scientists operating marine mammal surveys in these areas should be encouraged to collect data on sperm whales, including the sex and apparent maturational status of animals, together with (if possible) biopsy samples for genetic analysis.

The information provided by this project adds to existing data on the spatial and temporal distribution of sperm whales in the NP, and will, we hope, assist in the design of future surveys to study the abundance, distribution, and ecology of this species as it slowly recovers from whaling.

Acknowledgements. This was North Pacific Research Board (NPRB) Project Number 1209; we are grateful for NPRB's support of this work. We thank Cherry Allison, Jay Barlow, Grigori Derviz, Nikolai Doroshenko, Sarah Mesnick, Randy Reeves, Barbara Taylor, and Alex Zerbini for their input to this study, and 4 anonymous reviewers for their comments.

\section{LITERATURE CITED}

Allen BM, Angliss RP (2013) Alaska marine mammal stock assessments, 2012. NOAA Technical Memorandum NMFSAFSC-245. US Department of Commerce, Seattle, WA

Allison C (2012) International Whaling Committee summary database, Version 5.2. International Whaling Commission, Cambridge

Anonymous (1956) Promisloviy otchet 2-oy Dalnevostochnoy Kitoboinoy flotilii za 1956 god [Whaling production report of the 2nd Far Eastern whaling fleet for 1956],
Upravlenie proizvodstvennikh flotiliy 'Dal'moreprodukt', Vladivostok (in Russian)

Barlow J, Taylor BL (2005) Estimates of sperm whale abundance in the northeastern temperate Pacific from a combined acoustic and visual survey. Mar Mamm Sci 21: 429-445

Berzin AA (1972) The sperm whale. Israel Program for Scientific Translations, Jerusalem

Berzin AA (2008) The truth about Soviet whaling. [Translation: Y.V. Ivashchenko]. In: Ivashchenko YV, Clapham PJ, Brownell RL Jr (eds) The truth about Soviet whaling: a memoir. Mar Fish Rev 70:4-56

Best PB (1979) Social organization in sperm whales, Physeter macrocephalus. In: Winn HE, Olla BL (eds) Behavior of marine animals: current perspectives in research, Vol 3. Cetaceans. Plenum Press, New York, NY, p 227-289

Brownell RL Jr, Yablokov AV, Zemsky VA (2000) USSR pelagic catches of North Pacific sperm whales, 19491979: conservation implications. In: Yablokov AV, Zemsky VA (eds) Soviet whaling data (1949-1979). Center for Russian Environmental Policy, Moscow, p 123-130 (in Russian and English)

Clapham P, Baker CS (2008) Modern whaling. In: Perrin WF, Würsig B, Thewissen JGM (eds) Encyclopedia of marine mammals. Academic Press, San Diego, CA, p 1239-1243

Clapham P, Ivashchenko Y (2009) A whale of a deception. Mar Fish Rev 71:44-52

Donovan GP (1991) A review of IWC stock boundaries. Rep Int Whal Comm (Spec Issue 13):39-68

Doroshenko NV, Rovnin AA, Davidova GD, Tarasevich MN (1965) Biologicheskie obosnovaniya razvitiya i ratsional'nogo vedeniya promisla morskikh mlekopitayshchikh, [Biological rational and sustainable management of marine mammal harvest]. VNIRO, Moscow

Dufault S, Whitehead H, Dillon M (1999) An examination of the current knowledge on the stock structure of sperm whales (Physeter macrocephalus) worldwide. J Cetacean Res Manag 1:1-10

Fearnbach H, Durban JW, Mizroch S, Barbeaux S, Wade P (2012) Winter observations of a group of female and immature sperm whales in the high-latitude waters near the Aleutian Islands, Alaska. Mar Biodivers Rec 5:1-4

> Ivashchenko YV, Clapham PJ (2012) Soviet illegal catches of North Pacific right Eubalaena japonica and bowhead Balaena mysticetus whales in the North Pacific and the Okhotsk Sea. Endang Species Res 18:201-217

Ivashchenko YV, Clapham PJ (2014) Too much is never enough: the cautionary tale of Soviet whaling. Mar Fish Rev 76:1-21

Ivashchenko YV, Clapham PJ, Brownell RL Jr (eds) (2007) Scientific reports of Soviet whaling expeditions in the North Pacific, 1955-1978 [Translation: YV Ivashchenko]. NOAA Technical Memorandum NMFS-AFSC-175, US Department of Commerce, Seattle, WA

Ivashchenko YV, Clapham PJ, Brownell RL Jr (2011) Soviet illegal whaling: the Devil and the details. Mar Fish Rev 73:1-19

Ivashchenko YV, Clapham PJ, Brownell RL Jr (2013) Soviet catches of whales in the North Pacific: revised totals. J Cetacean Res Manag 13:59-71

IWC (International Whaling Commission) (1974) Report of the International Whaling Commission, Appendix III. Chairman's report of the 24th meeting, London. Rep Int Whal Comm 24:20-36

Kasuya T (1991) Density-dependent growth in North Pacific 
sperm whales. Mar Mamm Sci 7:230-257

Kasuya T, Miyashita T (1988) Distribution of sperm whale stocks in the North Pacific. Sci Rep Whales Res Inst 39: 31-75

Klumov SK (1959) Otchet expeditsii instituta okeanologii AN SSSR i TINRO po izucheniyu dal'"nevostochnikh kitoobraznikh za 1951-56gg [Expedition report by the Institute of Oceanography AN USSR and TINRO on the studies of Far-eastern cetaceans during 1951-56]. TINRO, Vladivostok (in Russian)

Mizroch SA, Rice DW (2013) Ocean nomads: distribution and movements of sperm whales in the North Pacific as shown by whaling data and Discovery marks. Mar Mamm Sci 29:E136-E165

Polovina J, Uchida I, Balazs G, Howell EA, Parker D, Dutton P (2006) The Kuroshio Extension Bifurcation Region: a pelagic hotspot for juvenile loggerhead sea turtles. Deep-Sea Res II 53:326-339

Qiu B (2001) Kuroshio and Oyashio Currents. In: Encyclopedia of ocean science. Academic Press, New York, NY, p 1413-1425

Rocha RC, Clapham PJ, Ivashchenko YV (in press) Emptying the oceans: a summary of industrial whaling catches in the 20th century. Mar Fish Rev

Smith TD, Reeves RR, Josephson EA, Lund JN (2012) Spatial and seasonal distribution of American whaling and whales in the Age of Sail. PLOS One 7:e34905

Starbuck A (1878) History of the American whale fishery from its earliest inception to the year 1876. Castle Books, Secaucus, NJ (reprinted 1989)

Tarasevich MN (1965) Distribution of sperm whales in the northern region of Kuril waters, 1959-61. In: Pavlovskiy

Editorial responsibility: Sascha Hooker, St. Andrews, UK
EN (ed) Marine mammals. Nauka, Moscow, p 38-42

Tarasevich MN (1968) Food connections of the sperm whales in the North Pacific. Zool Zh 47:395-401

Tarasevich MN, Borisov VI (1962) Svodka o sostoyanii promisla i ego perspektivakh v raione Kurilskikh ostrovov. [Summary of whaling conditions and its prospects in the Kuril Islands area.] VNIRO, Moscow (in Russian)

Townsend C (1935) The distribution of certain whales as shown by logbook records of American whaleships. Zoologica 19:1-50

Wade PR, Gerrodette T (1993) Estimates of cetacean abundance and distribution in the eastern tropical Pacific. Rep Int Whaling Comm 43:477-493

Whitehead H (2003) Sperm whales: social evolution in the ocean. University of Chicago Press, Chicago, IL

Whitehead H, Antunes R, Gero S, Wong SNP, Engelhaupt D, Rendell L (2012) Multilevel societies of female sperm whales (Physeter macrocephalus) in the Atlantic and Pacific: Why are they so different? Int J Primatol 33: 1142-1164

Yablokov AV, Zemsky VA (eds) (2000) Soviet whaling data (1949-1979). Center for Russian Environmental Policy, Moscow (in Russian and English)

Yablokov AV, Zemskiy VA, Berzin AA, Mikhalev YA, Tormosov DD (1995) Soviet Antarctic whaling data (19471972). Center for Russian Environmental Policy, Moscow (in Russian and English)

Yablokov AV, Zemsky VA, Mikhalev YA, Tormosov DD, Berzin AA (1998) Data on Soviet whaling in the Antarctic in 1947-1972 (population aspects). Russ J Ecol 29:38-42

Yasuda I (2003) Hydrographic structure and variability in the Kuroshio-Oyashio transition area. J Oceanogr 59:389-402

Submitted: April 27, 2014; Accepted: August 6, 2014

Proofs received from author(s): September 16, 2014 